\title{
DUKUNGAN KELUARGA DAN KUALITAS HIDUP ORANG DENGAN HIV/AIDS DI LANTERA MINANGKABAU SUPPORT
}

\author{
Dwi Novrianda*, Yonrizal Nurdin*, Gusnita Ananda** \\ *Dosen Fakultas Keperawatan Universitas Andalas, Jl. Limau Manis, Kecamatan Pauh, \\ Sumatera Barat 25163, Indonesia \\ ** Mahasiswa Program Studi S1 Ilmu keperawatan Fakultas keperawatan Universitas Andalas \\ Email : dwinov_82@yahoo.co.id
}

\begin{abstract}
ABSTRAK
Pendahuluan: Permasalahan yang timbul akibat HIV/AIDS sangat kompleks, diantaranya masalah fisik, psikologis, sosial dan spiritual yang mempengaruhi kualitas hidup. Ini dapat mempengaruhi kualitas hidup orang dengan HIV/AIDS (ODHA) sehingga memerlukan dukungan keluarga. Tujuan dari penelitian ini adalah untuk mengetahui hubungan dukungan keluarga dengan kualitas hidup pada ODHA. Metode: Jenis penelitian deskriftif analitik dengan pendekatan cross sectional study. Penelitian dilakukan di Lantera Minangkabau Support Padang selama 18 hari dari tanggal 23 Desember 2014 - 09 Januari 2015. Besar sampel 106 orang yang diambil secara accidental sampling. Hasil: Hasil penelitian menunjukkan sebanyak 63 orang $(59,4 \%)$ responden mendapatkan dukungan yang baik dari keluarga dan 61 orang $(57,5 \%)$ responden memiliki kualitas hidup yang baik. Uji chi-square menunjukkan terdapat hubungan antara dukungan keluarga dengan kualitas hidup ODHA $(\mathrm{p}=0,000)$. Diskusi: Maka disimpulkan jika dukungan keluarga baik, kualitas hidup ODHA juga baik. Oleh karena itu perlu melibatkan keluarga dalam pertemuanpertemuan untuk memotivasi.
\end{abstract}

Kata kunci: dukungan keluarga, kualitas hidup, orang dengan HIV/AIDS 


\section{PENDAHULUAN}

Data Badan Kesehatan Dunia (WHO) tahun 2008-2011 melaporkan terdapat 2 juta kematian terkait AIDS. Hingga bulan Desember 2008 tercatat 33,4 juta ODHA tersebar di seluruh dunia, termasuk 2,7 juta kasus orang yang baru tertular HIV. Jumlah ini terus bertambah dengan kecepatan 15.000 kasus baru per hari, dengan estimasi 5 juta pasien baru terinfeksi HIV setiap tahunnya di seluruh dunia. Oleh karena itu penyakit ini telah menjadi penyakit mematikan teratas di antara penyakit infeksi lainnya dan menduduki ranking keempat penyebab kematian di dunia (Kementrian Kesehatan, 2013).

Sumatera Barat pada tahun 2013 terjadi peningkatan kasus HIV di mana laki-laki yang terinfeksi HIV sebanyak 61\% dan perempuan 39\%. Data yang didapat dari Dinas Kesehatan Kota Padang jumlah penderita AIDS di Kota Padang dari tahun 2008 sampai 2014 sebanyak 355 orang. Data terakhir menunjukkan angka kematian akibat HIV/AIDS dari 2008 sampai 2014 sebanyak 38 orang.

Berbagai reaksi muncul ketika seseorang didiagnosa menderita HIV/AIDS seperti perasaan takut, menyesal, mencoba menyangkal, depresi, bingung serta tidak tahu yang harus dilakukan. Mengidap HIV/AIDS masih dianggap aib, sehingga dapat menyebabkan tekanan psikologis terutama pada penderitanya maupun pada keluarga dan lingkungan di sekeliling penderita (Nursalam, 2007). Pemahaman yang berkembang di masyarakat terhadap ODHA membuat masyarakat cenderung bersikap mengucilkan ODHA. Kondisi ini akan membuat ODHA semakin menutup dirinya dari kehidupan sosialnya sehingga semakin memperburuk kondisi ODHA.

Akibat dari stigma tersebut penderita ODHA sering merasakan feeling blue (kesepian, putus asa, cemas dan depresi) sehingga dapat dikatakan bahwa kualitas hidup ODHA dari segi psikologis kurang baik. Berbagai masalah psikologis ini dapat mempengaruhi kemampuan ODHA untuk berpartisipasi secara penuh dalam pengobatan dan perawatan dirinya, sehingga berdampak terhadap kualitas hidup ODHA (Hardiansyah, 2011).

Kualitas hidup dianggap sebagai suatu persepsi subjektif multidimensi yang dibentuk oleh individu terhadap fisik, emosional, dan kemampuan sosial termasuk kemampuan kognitif (kepuasan) dan komponen emosional atau kebahagiaan. Penyakit HIV/AIDS adalah penyakit yang dapat mempengaruhi kualitas hidup pasien. Sesuai 
dengan hasil penelitian yang dilakukan oleh Nojomi dkk (2008) didapatkan bahwa mayoritas pada penderita HIV/AIDS baik simptomatik maupun yang nonsomptomatik memiliki nilai kualitas hidup yang rendah. Hasil penelitian Hardiansyah (2011) diketahui gambaran kualitas hidup ODHA di Kota Makassar adalah buruk 11 orang $(52,4 \%)$.

Di dalam hasil penelitian Hardiansyah (2011) merekomendasikan agar dapat meningkatan kualitas hidup ODHA maka keluarga harus mampu memberikan rasa aman pada ODHA yang berada di lingkungan tempat tinggalnya dengan tidak menghindari, mengasingkan serta tidak menolak keberadaannya. Selain itu memberikan dukungan kepada ODHA dapat juga berupa pemberian informasi, bantuan tingkah laku ataupun materi sehingga ODHA merasa diperhatikan, bernilai dan dicintai

Adapun faktor-faktor yang mempengaruhi kualitas hidup pada ODHA antara lain: persepsi kesehatan, emosi, energi/kelelahan, tidur, fungsi kognitif, kegiatan fisik dan kegiatan harian, teknik mengatasi masalah, masa depan, gejala, pengobatan dan dukungan sosial. Dukungan sosial diperoleh dari dukungan keluarga, dukungan teman sebaya, dan dukungan masyarakat (Michael Carter, 2012).

Beberapa faktor yang mempengaruhi kualitas hidup ODHA telah dikemukakan diatas, hal yang perlu diperhatikan pada ODHA adalah dukungan keluarganya, karena Penderita ODHA masih banyak yang kurang mendapatkan dukungan dari keluarga. Hal ini disebabkan oleh karena tingginya stigma yang terkait dengan penyakit HIV/ AIDS sehingga anggota keluarga yang menderita penyakit ini sering kali dianggap telah melanggar norma-norma dalam keluarga dan memalukan keluarga sehingga sering kali dikucilkan atau di telantarkan bahkan di isolasi dari lingkungan (Purnama \& Haryanti, 2006).

Di dalam penelitian Eni Nuraeni (2011) bahwa seorang konselor HIV/AIDS mengungkapkan, kebutuhan utama ODHA adalah orang-orang terdekat seperti keluarga. Keluarga yang mampu menerima kondisi ODHA, terus mendampingi pada masa sulit, mengantar berobat ke dokter, membantu mencari dan memberi informasi tentang penyakit HIV/AIDS, dapat membuat ODHA merasa dihargai dan hidupnya menjadi lebih berarti. Dengan hasil penelitiannya dari 20 ODHA masih terdapat 13 ODHA $(65 \%)$ memiliki dukungan keluarga yang rendah. 
Hasil penelitian Kamath dan Mohanna (2009) menunjukkan bahwa dukungan keluarga dapat memberikan dampak positif terhadap penurunan gangguan jiwa pada ODHA seperti kecemasan, stress, depresi dan rasa kesendirian, Penelitian yang juga dilakukan oleh Adeyemi Oluwagbemiga (2007) menyatakan bahwa pasien dengan HIV positif yang mendapat dukungan keluarga akan mengalami gejala depresi yang lebih ringan. Hasil penelitian dari Cichocki (2009) terhadap pasien HIV/AIDS yang menjalani perawatan dirumah sakit menemukan bahwa $40 \%$ dari pasien HIV/AIDS tersebut mengalami depresi.

Dari penjelasan di atas diketahui bahwa pentingnya dukungan keluarga bagi ODHA. Hal tersebut didukung dari hasil penelitian Diatmi (2014) yang merekomendasikan agar penelitian selanjutnya dapat mengkhususkan sumber dari dukungan sosial yang diperoleh ODHA, misalnya dukungan sosial yang diperoleh dari keluarga.

Di Lentera Minangkabau sangat mudah ditemukan pasien HIV/AIDS. Berdasarkan studi pendahuluan yang dilakukan pada hari Rabu, tanggal 15 Oktober 2014, jumlah ODHA di Yayasan Lantera Minangkabau sebanyak 188 orang. Salah satu koordinator lapangan di Yayasan Lantera Minangkabau mengatakan bahwa Lantera Minangkabau melakukan pertemuan rutin 3 kali dalam sebulan dengan ODHA. Pada setiap pertemuan membahas materi yang berbeda dan bertujuan untuk memberikan pengetahuan, dukungan dan motivasi pada ODHA yang mendapatkan pendampingan dari Lantera Minangkabau baik itu ODHA yang baru terinfeksi ataupun yang sudah lama.

Lebih lanjut diperoleh data sekitar 23\% dari 188 orang ODHA tidak tinggal bersama keluarganya lagi melainkan tinggal sendiri. Maka dengan demikian perlu diketahuinya bagaimana kaitan dukungan keluarga dan kualitas hidup ODHA di Lantera Minangkabau.

\section{METODE PENELITIAN}

Jenis penelitian ini adalah deskriptif analitik dengan pendekatan cross sectional study. Jumlah sampel sebanyak 106 ODHA di Lantera Minangkabau Support Padang Tahun 2014 dengan kriteria inklusi ODHA yang mempunyai keluarga dan tinggal dengan keluarga. ODHA yang mengalami gangguan kejiwaan dan memakai narkoba tidak diikutkan dalam penelitian ini. 
Instrumen yang digunakan berupa kuesioner yaitu kuesioner karakteristik responden, kuesioner kualitas hidup, dan kuesioner dukungan keluarga pada ODHA dimodifikasi dari Kusuma (2011). Setelah itu data dianalisis menggunakan uji ChiSquare dengan $p$ value $\leq 0,05$.

\section{HASIL DAN PEMBAHASAN}

Hasil dari penelitian ini meliputi karakteristik responden, dukungan keluarga, dan kualitas hidup ODHA. Tabel 2 menunjukkan hasil bahwa sebagian besar $(59,4 \%)$ responden mendapatkan dukungan yang baik dari keluarga. Lebih lanjut 57,5 \% responden memiliki kualitas hidup yang baik.

\section{Karakteristik responden}

Tabel 1. Karakteristik responden

\begin{tabular}{lllcc}
\hline $\begin{array}{l}\text { No. } \\
\text { Karakteristik } \\
\text { Responden }\end{array}$ & \multicolumn{1}{c}{ Kategori } & Frekuensi (f) & $\begin{array}{c}\text { Persentase } \\
(\%)\end{array}$ \\
\hline 1. & Umur & Remaja akhir (17-25 tahun) & 10 & 9,5 \\
& (Depkes RI, & Dewasa awal (26-35 tahun) & 52 & 49 \\
& 2009) & Dewasa akhir (36-45 tahun) & 42 & 39,6 \\
& Lansia akhir (56-65 tahun) & 2 & 1,9 \\
\hline 2. & Jenis Kelamin & Laki-laki & 42 & 77.4 \\
& & Perempuan & 24 & 22.6 \\
\hline 3. & Pendidikan & SD & 0 & 0 \\
& Terakhir & SMP/Sederajat & 4 & 3.8 \\
& & SMA/Sederajat & 88 & 83 \\
& & Perguruan Tinggi & 14 & 13.2 \\
\hline 4. & Pekerjaan & PNS & 2 & 1.9 \\
& & Wiraswasta & 66 & 62.3 \\
& & Petani & 4 & 3.8 \\
& Buruh/karyawan & 2 & 1.9 \\
& & Pedagang & 6 & 5.7 \\
& Lainnya & 16 & 15.1 \\
& Tidak bekerja & 10 & 9.4 \\
\hline
\end{tabular}

\section{Dukungan Keluarga dan Kualitas Hidup}

Tabel 2. Dukungan keluarga dan kualitas hidup (n=106)

\begin{tabular}{ccc}
\hline & f & \% \\
\hline Dukungan keluarga & & \\
Kurang baik & 43 & 40,6 \\
Baik & 63 & 59,4 \\
\hline Kualitas hidup & & \\
Kurang baik & 45 & 42,5 \\
Baik & 61 & 57,5 \\
\hline
\end{tabular}




\section{Dukungan Keluarga}

Hasil penelitian menunjukkan bahwa lebih dari separoh $(59,4 \%)$ mempunyai dukungan keluarga yang baik. Berdasarkan hasil jawaban responden yang banyak menjawab selalu mendapatkan dampingan dari keluarga dalam pengobatan penyakitnya. Hasil penelitian ini sama dengan hasil penelitian Nuraeni (2011) bahwa mayoritas responden memiliki dukungan keluarga yang baik yaitu sejumlah 13 orang $(65,0 \%)$, sedangkan yang memiliki dukungan keluarga yang kurang baik sebanyak 7 orang $(35,0$ $\%)$.

Berdasarkan jawaban responden dari pernyataan yang disebar melalui kuesioner, sebagian besar $(47,2 \%)$ responden menjawab kalau keluarga sering menunjukkan kepeduliannya terhadap ODHA, 59 orang $(55,7 \%)$ menjawab keluarga sering berperan aktif dalam setiap pengobatan dan perawatan sakitnya, sebagian besar $(60,4 \%)$ responden menjawab keluarga selalu berusaha untuk mencarikan kekurangan sarana dan peralatan perawatan yang diperlukan, lebih separoh $(65,1 \%)$ responden menjawab keluarga tidak pernah melarang ODHA untuk terlibat dalam kegiatan sosial di kampungnya.

Lebih lanjut, 46 orang $(43,4 \%)$ ODHA menunjukkan bahwa ODHA memiliki dukungan keluarga yang kurang baik. Berdasarkan jawaban responden masih banyak yang menjawab tidak pernah ataupun jarang diperhatikan dan dibantu keluarga dalam pengobatan. Hal ini sesuai dengan hasil penelitian Kusuma (2011) yaitu 51 orang (55,4 $\%)$ memiliki dukungan keluarga yang kurang baik. Hasil penelitian yang sama juga ditemukan oleh Nirmal (2008) yaitu 63 orang (58\%) memiliki dukungan keluarga yang kurang baik.

Menurut asumsi peneliti adanya responden yang mendapatkan dukungan keluarga yang kurang baik dari keluarga ODHA dipengaruhi oleh kurangnya pemahaman atau pengetahuan keluarga tentang penyakit HIV/AIDS. Selain itu hal ini juga dipengaruhi oleh lingkungan tempat tinggal mereka apabila ODHA tinggal di daerah perkampungan maka reaksi masyarakat negatif seperti terjadinya stigma dan diskriminasi yang ditimbulkan oleh lingkungan sekitarnya sehingga ODHA tidak mau membuka status HIV kepada keluarga, pasangan ataupun lingkungan. Hal ini diperkuat dengan hasil penelitian yang menyatakan bahwa rendahnya ODHA dalam membuka status HIV kepada orang terdekatnya termasuk kepada keluarga. Oleh sebab itu perlu adanya 
penjelasan informasi HIV/AIDS kepada keluarga sehingga tidak ada lagi ODHA dikucilkan.

\section{Kualitas Hidup}

Hasil penelitian menunjukkan bahwa lebih dari separoh yaitu 61 ODHA (57,5\%) mempunyai kualitas hidup yang baik. Hasil penelitian ini sama dengan hasil penelitian Rahmayuni (2014) bahwa mayoritas responden memiliki kualitas hidup baik yaitu sejumlah 26 orang $(61,9 \%)$, sedangkan yang memiliki kualitas hidup yang kurang baik sebanyak 16 orang $(38,1 \%)$.

Berdasarkan jawaban responden dari pernyataan yang disebar melalui kuesioner, sebagian besar $(45,3 \%)$ responden menjawab sering merasa puas terhadap istirahat tidurnya, 55 orang $(51,9 \%)$ menjawab sering merasa puas dengan tenaga yang dimilikinya untuk beraktifitas, sebagian besar $(45,3 \%)$ responden selalu merasa dirinya berharga, lebih dari separoh $(51,9 \%)$ responden menjawab sering merasa puas terhadap dukungan dan pelayanan kesehatan yang diterimanya, namun (20,7 \%) responden mengatakan sering merasa terganggu dengan kondisi sakit yang menghambat aktifitas sehari-harinya.

ODHA yang memiliki kualitas hidup kurang baik pada beberapa responden yaitu 45 orang (42,5\%). Dari jawaban responden dalam kuesioner, 16 orang $(15,1 \%)$ ODHA selalu merasa terganggu dengan kondisi sakit yang menghambat dalam aktifitas sehariharinya dan 50 orang $(47,2 \%)$ ODHA sering merasa orang-orang di sekitarnya tidak menyukainya dan menghindar darinya. Hal ini sesuai dengan hasil penelitian Nojomi (2008) yaitu 80 orang (73\%) ODHA dalam penelitiannya mempersepsikan kualitas hidup yang kurang baik. Hasil penelitian yang sama juga ditemukan oleh Kusuma (2011) yaitu 58 orang (63\%) memiliki kualitas hidup yang kurang baik.

Kualitas hidup ini merupakan faktor penting yang perlu diperhatikan untuk kesehatan mental maupun fisik ODHA yang dapat memberikan kontribusi terhadap kepuasan dan kebahagiaan dari individu itu sendiri serta memberikan manfaat kepada keluarga dan masyarakat (Mardhiati, 2011).

Dalam meningkatkan kualitas hidup ODHA ada lima pilar yang harus dimiliki yaitu memiliki kepercayaan diri, memiliki pengetahuan tentang HIV/AIDS, memiliki akses ketersediaan layanan dukungan (keluarga maupun teman sebaya), pengobatan dan 
perawatan, tidak menularkan virus ke orang lain dan melakukan kegiatan positif (Mardhiati, 2011).

\section{Hubungan Dukungan Keluarga Dengan Kualitas Hidup ODHA}

Tabel 3. Uji chi-square dukungan keluarga dan kualitas hidup ODHA

\begin{tabular}{cccc}
\hline Dukungan keluarga & \multicolumn{2}{c}{ Kualitas hidup } & \multirow{2}{*}{ p Value } \\
\cline { 2 - 3 } & Kurang baik & Baik & \\
\hline Kurang baik & $38(88,4 \%)$ & $5(11,6 \%)$ & 0,000 \\
\hline Baik & $7(11,1 \%)$ & $56(88,9 \%)$ & \\
\hline
\end{tabular}

Pada tabel 3 dapat dilihat responden yang memiliki dukungan keluarga baik memperlihatkan hampir seluruhnya $(88,9 \%)$ kualitas hidup ODHA baik dan sebagian kecil $(11,1 \%)$ kualitas hidupnya kurang baik. Kemudian dukungan keluarga yang kurang baik menghasilkan sekitar 88,4\% kualitas hidup ODHA kurang baik. Uji chisquare menunjukkan ada hubungan antara dukungan keluarga dengan kualitas hidup responden secara signifikan $(\mathrm{p}=0,000)$.

Berdasarkan hasil penelitian didapatkan bahwa persentase kualitas hidup yang baik lebih besar pada responden dengan dukungan keluarga yang baik yaitu 56 orang (36,3 $\%$ ) dibandingkan dengan responden dengan dukungan keluarga kurang baik yaitu 5 orang $(24,7 \%)$. Dari uji statistik diperoleh nilai $(\mathrm{p}=0,000, \mathrm{p}<0,05)$ menunjukkan ada hubungan yang bermakna antara dukungan keluarga dengan kualitas hidup responden

Hampir sama dengan hasil penelitian kusuma (2011) yang menunjukkan bahwa dukungan keluarga mempunyai hubungan yang signifikan dengan kualitas hidup pasien HIV/AIDS yang menjalani perawatan di RSUPN Cipto Mangunkusumo Jakarta dan kekuatan hubungannya sedang yang berpola positif $(\mathrm{p}=0,001, \alpha=0,05)$. Hasil penelitian menunjukkan bahwa semakin baik dukungan keluarga maka semakin baik kualitas pasien HIV/AIDS yang menjalani perawatan di RSUPN Cipto Mangunkusumo Jakarta.

Pada penelitian Li (2009) diketahui juga bahwa orang yang hidup dengan HIV/AIDS sangat membutuhkan bantuan dan dukungan dari keluarga karena penyakit ini bersifat kronis dan membutuhkan penanganan yang komprehensif. Dukungan keluarga tersebut meliputi dukungan emosional, dukungan penghargaan, dukungan informasi dan instrumental.

Dukungan keluarga dapat berupa sikap, tindakan, dan penerimaan keluarga terhadap penderita yang sedang sakit. Pada penelitian ini, keluarga telah mengetahui 
bahwa anggota keluarganya menderita HIV/AIDS. Dukungan yang diterima oleh ODHA dari keluarga merupakan dukungan yang sangat berarti bagi ODHA. ODHA merasa dukungan yang didapatkan dari keluarga merupakan bentuk kepedulian keluarga terhadap dirinya serta menunjukkan ODHA masih dianggap sebagai bagian dari keluarga walaupun saat ini menderita HIV/AIDS.

Dukungan keluarga yang diterima ODHA juga merupakan bentuk dukungan dari keluarga yang dapat mengurangi stress akibat berbagai masalah fisik, psikologis maupun sosial yang sering dihadapi ODHA. Hal ini sesuai dengan Friedman (2010), dukungan keluarga dapat berfungsi sebagai strategi pencegahan untuk mengurangi stress, dengan cara keluarga memberikan semangat dan motivasi serta menghibur ODHA.

Menurut Nojomi dalam penelitiannya, agar terjadi peningkatan kualitas hidup ODHA harus merasa aman berada di lingkungan tempat tinggalnya dengan cara keluarga tidak menghindari, mengasingkan serta tidak menolak keberadaannya, memberikan dukungan kepada ODHA berupa pemberian informasi, bantuan tingkah laku ataupun materi sehingga ODHA merasa diperhatikan, bernilai dan di cintai.

Selain dari dukungan keluarga dukungan dari orang-orang terdekat sangat dibutuhkan juga oleh ODHA. Salah satu contoh yaitu dukungan dari teman sebaya, seperti dukungan kelompok sebaya sangatlah penting bagi ODHA dengan memberikan semangat atau dukungan dalam menjalani pengobatan. Kesebayaan disini diartikan sebagai kesamaan dalam perilaku beresikonya, orientasi seksual, usia, status sosial, dan sebagainya. Jadi setiap kelompok dukungan sebaya mempunyai spesifikan anggota tersendiri. Karena unsur kesamaan atau kesebayaan orang-orang di dalamnya akan merasa lebih nyaman dan saling terbuka, lebih leluasa mengeluarkan pikiran, lebih mudah merasakan dan memahami permasalah yang ada di komunitasnya (USAID, 2011).

\section{KESIMPULAN}

Berdasarkan hasil penelitian yang dilakukan mengenai dukungan keluarga dengan kualitas hidup ODHA di Lantera Minangkabau Support Padang Tahun 2014, dengan sampel sebanyak 106 orang, maka dapat diambil kesimpulan bahwa lebih dari separoh ODHA $(57,5 \%)$ mempunyai dukungan keluarga yang baik. Lebih dari separoh ODHA 
$(59,4 \%)$ mempunyai kualitas hidup yang baik. Ada hubungan yang bermakna antara dukungan kuluarga dengan kualitas hidup di Lantera Minangkabau Support Padang Tahun 2014, dimana $(\mathrm{p}=0,000)$.

Bagi pihak lantera agar dapat melibatkan keluarga dalam pertemuan-pertemuan untuk memotivasi ODHA terutama untuk ODHA yang baru terinfeksi, dimana pihak Lantera juga mengikutsertakan keluarga dalam kegiatan yang diadakan di Lantera untuk menjalin komunikasi yang baik dengan keluarga mengenai dukungan yang diinginkan atau dibutuhkan ODHA dari keluarga. Harapannya agar mempermudah memberikan solusi yang tepat dari berbagai permasalahan baik fisik, psikologis maupun sosial bagi ODHA. Penelitian ini dapat menjadi rujukan untuk melakukan penelitian lebih lanjut tentang dukungan dari orang-orang terdekat ODHA seperti dukungan kelompok sebaya.

\section{DAFTAR PUSTAKA}

Carter, M. (2012). Study identifies issues affecting the quality of life of patients living with HIV. Diakses pada tanggal 23 November 2014 dari http://mobile.aidsmap.com/Study-identifies-issues-affecting-the-quality-of-life-ofpatients-living-with-HIV/page/220212.

Depkes RI. (2013). Peraturan Menteri Kesehatan Republik Indonesia Nomor 21 Tahun 2013 tentang penanggulangan Hiv Dan Aids. Diakses pada tanggal 4 November 2014 melalui http://pppl.depkes.go.id/_asset/_regulasi/100 _Permenkes\%20No\%2021\%20Tahun\%202013\%20Penanggulangan\%20HIVAIDS. pdfn

Diatmi, K., \& Fridari, D. (2014). Hubungan antara dukungan sosial dengan kualitas hidup pada orang dengan HIV dan AIDS (ODHA) Di Yayasan Spirit Paramacitta. Diakses pada tanggal 30 November 2014 dari http://ojs.unud.ac.id/index.php/psikologi/article/downloud/8549/6408

Dinas Kesehatan Kota Padang. (2014). Jumlah penderita AIDS Tahun 2008-2013. Padang

Dinas Kesehatan Provinsi Sumbar. (2013). Strategi penanggulangan HIV/AIDS Di Indonesia dan Sumatera Barat. Padang.

Friedman. (2010). Keperawatan Keluarga. Jakarta: EGC 
Hardiansyah, A. (2011). Kualitas hidup orang dengan HIV dan AIDS di kota Makassar. $\begin{array}{llllll}\text { Diakses } & \text { pada } & \text { tanggal } & 23 & \text { oktober } & 2014\end{array}$ http://prosiding.lppm.unisba.ac.id/index.php/sosial/article/viewFile/102/52

Kamath \& Mohanna. (2009). Family support in reducing morbidity and mortality in hiv-infection person. American Psychiatric Journal. Diakses pada tanggal 24 oktober 2014 dari http://www.healthinsite.gov .au/topics/Social_Support_and_Research_into_HIV_and_AIDS

Kemenkes. (2012). Profil Kesehatan Indonesia Tahun 2011. Diakses Tanggal 3 Oktober 2014 dari http://www.depkes.go.id/resources/download/pusdatin/profil-kesehatanindonesia/profil-kesehatan-indonesia-2011.pdf

Kusuma, H. (2011). Hubungan antara depresi dan dukungan keluarga dengan kualitas hidup pasien HIV/AIDS yang menjalani perawatan di RSUPN Cipto Mangunkusumo Jakarta. Tesis Fakultas Ilmu Keperawatan Universitas Indonesia.

Lantera Minangkabau. (2011). Profil Lantera Minangkabau. Diakses Tanggal 20 Oktober 2014 dari http://lanteraminangkabau.wordpress.com/about.

Li li., Sheng, W., Zunyou, W., Stephani, S., Halxia, C \& Manhong, C. (2006). Understanding family support for people living with HIV/AIDS in Yunnan, China. Diakses pada tanggal 22 oktober 2014 dari http://www.ncbi.nlm.nih.gov/pmc/articles/PMC2584319/pdf/AFSH0802-0097

Li li., Sheng, W., Zunyou, W., Stephani, S., Halxia, C \& Manhong, C. (2009). Stigma, social support, and depression among people living with HIV in Thailand. Diakses pada tanggal $22 \quad$ oktober 2014 dari http://www.ncbi.nlm.nih.gov/pmc/articles/PMC2584319/pdf/AFSH0802-0097

Mardhiati, S. (2009). Perbandingan mutu hidup ODHA dengan system dukungan keluarga berdasarkan wilayah di Indonesia. Skripsi. Fakultas Ilmu kesehatan Universitas Muhammadiyah Prof. Dr. Hamka.

Nojomi, M, dkk (2008). Health-related quality of life in patients with HIV/AIDS. Archives of Iranian Medicine. Vol.11. Number 6. Diakses pada tanggal 21 Oktober 2014 dari http://ams.ac.ir

Nugrahawati, dkk. (2014). Hubungan antara dukungan keluarga dengan self esteem pada ODHA di Yayasan Akses Tasikmalaya. Diakses pada tanggal 23 oktober 2014 dari http://prosiding.lppm.unisba.ac.id/index.php /sosial/article/viewFile/102/52 
Jurnal Ilmu Keperawatan Medial Bedah 1 (1), Mei 2018, 1-43

ISSN 2338-2058 (print), ISSN 2621-2986 (online)

Nursalam, N. (2011). Asuhan keperawatan pada pasien terinfeksi HIV/AIDS. Jakarta: Salemba Medika

Oluwagbemiga, A. (2007). HIV/AIDS and family support systems: A situation analysis of people living with HIV/AIDS in Lagos State. Diakses pada tanggal 26 oktober 2014 dari http://gateway.nlm.nih.gov/meeting/ ma?f=102253707.html 